\title{
Relations between France and China: the Break ... with Germany?
}

Compiled and commented Analysis

\section{Mathieu Duchâtel}

\section{OpenEdition}

\section{Journals}

Electronic version

URL: http://journals.openedition.org/chinaperspectives/2673

DOI: $10.4000 /$ chinaperspectives. 2673

ISSN: 1996-4617

\section{Publisher}

Centre d'étude français sur la Chine contemporaine

Printed version

Date of publication: 15 December 2007

ISSN: 2070-3449

\section{Electronic reference}

Mathieu Duchâtel, « Relations between France and China: the Break ... with Germany? », China

Perspectives [Online], 2007/4 | 2007, Online since 09 April 2008, connection on 15 September 2020.

URL : http://journals.openedition.org/chinaperspectives/2673 


\section{Relations between France and China: the Break ... with Germany?}

Compiled and commented by Mathieu Duchâtel, based on:

- Luo Shaolan, "Sarkozy's visit to China, a mission to set the tone for France-China relations." Yazhou shibao zaixian (atchinese.com), 26 November 2007.

- Luo Shaolan, "China's relations with Germany: are they cooling off?" Yazhou shibao zaixian (atchinese.com), 26 November 2007.

- Pan Xiaoshou, "Allowing Sarkozy to touch the Terracotta army: what did it mean?" Yazhou shibao zaixian (atchinese.com), 27 November 2007.

T President Sarkozy was welcomed to China as no foreign head of state has been welcomed since President Clinton in 1998: nearly 20 billion euros' worth of contracts, a lavish dinner with $\mathrm{Hu}$ Jintao (French haute cuisine rather than the customary Chinese specialities), and permission to touch the precious soldiers of Emperor Qin
Shihuang's Terracotta Army in Xian. Pan Xiaoshou writes that Beijing's evident intention was to soften him up (keyi taohao). Back in 1998, Beijing needed a substantial improvement in its relations with Washington. Today, now that China's international standing has considerably improved and its relations with France are far from being in crisis, why 
are the leaders in Beijing laying on such a fine reception for President Sarkozy?

First of all, the two countries' interests really are complementary. Paris needs big contracts to keep big business interests firmly behind the government, to improve France's trade balance and to reduce the public deficit. France wishes to maintain economic cooperation and trade exchanges as the driving force behind its relations with China, while keeping its approach constructive and pragmatic and seeking to win Beijing's cooperation over issues it considers important, such as the fight against global warming. Beijing, for its part, needs an ally within the European Union to defend Chinese interests there, with a particular view to lifting the embargo on arms sales at some future date. Above all, China is always avid for technology transfers, to rebuild its industrial base and, in the longer term, to become a technological power in its own right, capable of rivalling the West, or at least of being less dependent upon it. From this point of view, Sarkozy's reputed Atlanticism has no effect on Franco-Chinese relations. Between Paris and Beijing, the honeymoon continues.

But the importance that China attaches to France may be explained by a new factor: the change of attitude in Berlin, where the government has decided to take a harder line towards Beijing. As a consequence, according to Pan, China has found it essential to compensate for the cooling down of its relations with Germany by strengthening its friendship with France. So China brought its usual strategy back into play: divide and rule. Here Beijing perceives a double advantage. Firstly, it can secure for China a provider of technology: this at a time when the US, Japan, and Germany are adopting a cautious approach to the usefulness of transferring technology to a state whose strategic intentions are still opaque. Secondly, it can attempt to maintain the policy of "using Europe to counter the US" (la'ou zhimei), or, at the very least, to prevent a Western common front in support of democracy and human rights. From this perspective, France was the best prospect.

Paris had chosen its moment. In Germany, the Christian Democrats (CDU) were in the process of reshaping their Asia policy: Paris then opted to go it alone on the China front, without seeking any joint stance with Berlin. On 26 October, Chancellor Angela Merkel unveiled the new Asia policy as set out by the CDU in an independent report. ${ }^{(3)}$ The policy includes some significant adjustments, but does not challenge the basic necessity for a close partnership with China. The CDU judges that, in the past, Berlin relied too heavily on Beijing to conduct its Asia policy, and that it is time for German strategy to be realigned so as to take full account of the democratic states in the region, such as Japan, South Korea, and India. The CDU considers that Berlin, blinded by the economic and commercial opportunities offered by the emergence of China, attached insufficient importance to the serious challenge it poses to the environ- ment, to defending the model of liberal democracy across the world, or to respecting the market economy rules that ought to govern the development of the new Asian power. The policy change was reflected in actions: in Berlin, on 23 September, Chancellor Merkel received the Dalai Lama, which threw Chinese leaders into a fury. Luo Shaolan assesses the CDU's report as the reintroduction of ideology into German foreign policy. This wave of disapproval for China was not limited to the German federal authorities: it extended equally across society in this most populous of European countries. At the end of August, the weekly Der Spiegel published a special report condemning China for orchestrating a wide-ranging campaign of technological espionage; ${ }^{(4)}$ the report provoked a serious debate, which damaged China's reputation and brought open protests from Germany's Chinese community. Luo writes that the wind has changed and the era of harmonious relations passed with the departure of Chancellor Schroeder. Some observers had foreseen a similar development in France, with a new President elected on a programme of breaking with the past, an avowed Atlanticist sensitive to the theme of an ethical foreign policy - but it was not to be. At a time when the European Union invests great hopes in its relationship with China, the rift in the Franco-German partnership does not presage much success in forging a common foreign policy in this part of the world. •

\section{- Translated by Philip Liddell}

\section{Glossary}

guojia xingzheng xueyuan 國家行政學院

keyi taohao

刻意討好

la'ou zhimei

拉歐制美

xibu kaifa

3. Asia as a strategic challenge and opportunity for Germany and Europe. See also the analysis by Andreas Martin Fulda, "Germany's Ruling Party in Search for a Strategic Answer to Asia's Rise. New symbolism, some substantive change, much continuity," Commentary, China Policy Institute, University of Nottingham.

4. "Die Gelben Spione," Der Spiegel, $n^{\circ}$ 35, 27 August 2007. 